\title{
Geologistudiet
}

\section{- hvor galt står det i grunden til?}

\section{Af lektor Ole Rønø Clausen}

I GeologiskNyt 3/04 fremlagde geologerne Ole Christensen, Søren M. Kristiansen og Thomas Varming et interessant debatindlæg, hvor de spørger, om vore kandidater er immobile og/ellergeologiuddannelserne er utidssvarende. Nedenstående skulle gerne dokumentere, at geologiuddannelsen ikke er utidssvarende og i høj grad i bevægelse for tiden.

Netop fordi vi står i en tid med grundlæggende ændringer, er det vigtigt, at vi i tidens reformer og omlægninger er ajour med, hvad vore tidligere kandidater har erfaret $i$ deres erhvervskarriere, og hvad aftagere af vore kandidater ser af fremtidige krav til arbejdskraften. Jeg ser frem til en fortsat erfaringsudveksling og debat.

\section{Ny kandidatuddannelse}

Lad mig indledningsvis orientere om, at der fra 2003 på hele Naturvidenskabeligt Fakultet, Aarhus Universitet, er foregået en grundlæggende omlægning af studierne med indførelse af 4 kvarterer i stedet for 2 semestre, hurtige evalueringer, nye evalueringsmetoder, fagpakker uden for fagets egentlige kerneområde, bl.a. bevidst med det formal at gøre vores bachelorer og kandidater

\section{Vidste du:}

*At du kan købe alle de tidligere, ikke-udsolgte numre (p.t. 57 stk.) for kun $300 \mathrm{kr}$. (ekskl. porto $57,50 \mathrm{kr}$.)?

\section{Eller}

*At du kan købe et klassesæt med 30 numre for $450 \mathrm{kr}$. (ekskl. porto 57,50 kr.)?

\section{Eller}

*At du i hele oktober måned kan forære dig selv eller en bekendt et abonnement på GeologiskNyt til kun 220 kr.? bedre klædt på til at bestride jobs både i den private og offentlige sektor (noget tilsvarende er sket på Københavns Universitet fra 2004). Vi har skabt en ny kandidatuddannelse i teknisk geologi, der rekrutterer diplomingeniører og bachelorer i geologi.

Forfatterne kan være undskyldt i deres kritik, idet det tager nogen tid, inden de møder studerende/kandidater, der er uddannet efter den nye ordning, men det ændrer heldigvis ikke ved, at studiet er reformeret siden forfatterne selv var en del af det.

\section{Kandidat-studietiden 7-8 år}

Jeg er enig med forfatterne $i$, at 7-8 år er alt for lang tid for at opnå en kandidatgrad, idet det efter normeret tid kun bør tage 5 år. Tidsrummet fra optagelse på bacheloruddannelsen til kandidateksamen er ofte længere af en hel række grunde. Ungdomskulturens bredspektrede karakter med sabbatperioder, elitesport etc. kan og bør universitetet næppe forsøge at ændre. Flere stifter familie i studieperioden. Studieophold i udlandet giver en internationalisering, som er en væsentlig del af uddannelsen, men som også kan betyde en mindre studietidsforlængelse.

Det er alle faktorer, hvor lærerne har meget lille indflydelse. Alligevel er en samlet studietid på 7-8 år, som forfatterne angiver, slet ikke typisk nu, og reformerne af geologiuddannelsen vil forventeligt betyde, at de fleste afslutter inden for 6 år.

\section{Frafaldstal 30-40 \%}

Hvis den studerende opdager at være optaget på det forkerte studium, skal vedkommende naturligvis skifte studium. Det er både personligt og samfundsøkonomisk detrigtige valg. Undervisernes opgave er at sikre, at den studerende ikke skifter studium af de forkerte grunde dvs. egentligt har lysten, men ikke trives. Det mener jeg, at vi på Geologisk Institut sikrer ved at fremme et godt studiemiljø, gode fysiske og sociale rammer og ikke mindst 1. klasses undervisning. Det er således en fornøjelse at konstatere, at af årgang 2003 ved Geologisk Institut er der endnu ingen der er "faldet fra", og vi følger dem tæt for at sørge for, at det fortsætter.

Men der må meget gerne komme flere på de følgende årgange. Man taler meget om de unges motivation til at søge ind på uddannelsen. Ved de overhovedet, at vi findes? Vi arbejder målrettet på forøgelse af kendskabet til geologi i skolesystemet bl.a. gennem studiepraktik for gymnasieelever ("3 dage som geologistuderende"), opsøgende foredrag, gymnasieklassebesøg på Geologisk Institut samt "Natur i Teltet" rettet mod folkeskolen som fælles naturvidenskabelig aktivitet under Århus Festuge.

\section{Er ph.d.-graden fagligt ensporet?}

Det fremmanede billede af den ph.d.-studerende, som sidder isoleret i sit lønkammer og forsker på ubestemt tid til ingens glæde og ingen nytte i et emne efter eget valg, afspejler ikke dagens situation. Den moderne ph.d.-uddannelse involverer talrige deadlines, halvårlige statusrapporter, supplerende kurser, undervisningserfaring, obligatorisk udlandsophold og intensivt faglig vejledning.

Projekter er altid styret af en erfaren lærer, og ofte er der samarbejde med eksterne partnere fx omkring de benyttede data. Da normeret studietid er blandt optagelseskriterierne, og da ph.d.-studiet er bundet til en tidsbegrænset aflønning, afsluttes ph.d.-studiet oftest ganske nær de normerede 8 år, fraregnet eventuel barsel og anden formel orlov.

\section{Hvad nu?}

Alle de her nævnte tiltag har sammen med andre tiltag ændret studiet markant til det bedre. Vi er dog slet ikke færdige - og bliver det forhåbentligt aldrig - med at reformere, og her er erfaringsudveksling og debat om vort fag med nuværende og tidligere studerende, erhvervskontrakter og vores ledelse meget vigtig og velkommen. 